\title{
Nurse Residents' Perception of Nursing Residency Program in
}

Egypt

\author{
${ }^{1}$ Hossam Ali Ismail Elsayied, ${ }^{2}$ Prof.Dr/ Eman Salman Taie \\ ${ }^{3}$ Prof.Dr/ Samah Mohamed Abd-allah \\ ${ }^{1}$ Helwan University, ${ }^{2}$ Professor of nursing administration, Helwan University \\ ${ }^{3}$ Professor of nursing administration, Assuit University
}

\begin{abstract}
Background: Nursing shortage has been an issue of concern globally and in Egypt. New graduate nurses have difficulties during transition from student nurse to professional nurse due to gap between nursing faculty education and practice requirements. Nursing Residency Program is a new graduate program structured to expand clinical and professional competencies for nurses to enhance a smooth transition to nursing practice and prepare high calibers in nursing profession which will reflect positively on nursing care. The aim of this study was to explore the nurse residents' perception of nursing residency program in Egypt. Design: A descriptive research design was used in this study. Sample: The study subjects included (67) nurse residents' (22) from Helwan University, (8) from Ain Shams University and (37) from Assiut University. Tools: Two tools were used for data collection included: Nurse residents' Knowledge questionnaire to assess nurse resident knowledge about nursing residency program and Nurse residents' perception questionnaire to assess the nurse residents perception of nursing residency program in Egypt. Results: The study results revealed that nurse residents had sufficient knowledge and positive perception about nursing residency program. Conclusion: The study concluded that there was a positive correlation between knowledge and perception scores. Recommendation: Based on the study findings, it is needed to disseminate the nursing residency regulation to all faculties of nursing in Egypt to follow it.
\end{abstract}

Key words: Nursing residency program, nurse resident, nurse resident perception 


\section{INTRODUCTION}

Health care areas suffer from severe nursing shortage, inadequate preparation of nurses to practice and deficiency of lifelong learning skills (Benner et al, 2010; Staiger et al, 2012 and National Academy of Sciences, 2012). Additionally, limited budgets for continuing education programs; that affect organization's ability to provide comprehensive training programs for nurses (Association of Registered Nurses of Newfoundland and Labrador, 2014).To meet these challenges, an increasing number of new graduate nurses will be needed and these new graduate nurses must quickly acclimate to the new job to provide safe, quality and competent care (Theisen \& Sandau, 2013 and Harris, 2014).

Nursing residency programs have been recommended by the Institute of Medicine to support the new graduate nurses' transition into a new practice area (Institute of Medicine, 2011 and Varner \& Leeds, 2012). Also, Nursing Residency Program (NRPs) is a new graduate training program includes organizational orientation, practice based experience and supplemental activities structured to expand clinical and professional competencies for nurses (The commission on Collegiate Nursing Education, 2008 and American Association of Colleges of Nursing, 2014).

Nursing residency program applied in Egypt after the agreement of Supreme Council of Universities on the establishment of the nursing residency program for nurses after complete the internship year. Supreme Council of Universities put a regulation for the nursing residency program include: The main purpose of this program is to prepare high calibers in nursing profession which will reflect positively on nursing care (Supreme Council of Universities, 2010).

The benefits of the nursing residency program is to mainly improve the quality of patient care through developing, improving, and sustaining professional nursing organizations (Versant, 2014). Also, the purpose of the nursing residency program is to provide new graduate nurses opportunities to build skills in real settings (National Council of State Boards of Nursing, 2009; Ulrich et al, 2010 and Goode et al, 2013), 


\section{Participants and methods}

\section{Research design and setting}

A descriptive design was used in this study. The study was conducted in all faculties of nursing that applied the nursing residency program in Egypt which included faculty of nursing Helwan University at Badr University Hospital, Ain Shams University and Assiut University.

\section{Participants}

The study included (67) of the nurse residents during 2016 distributed as the following: (22) in Helwan University, (8) in Ain Shams University and (37) in Assiut University). The mean score of the study subjects' age were $(25.7 \pm 1.2)$ years ranging from 24 to 31 years. Also, the majority of the nurse residents were females.

\section{Tools of data collection:}

Tool 1: Nurse Residents' Knowledge questionnaire: It was developed by the researcher after reviewing relevant literature (Allison, 2015) and consulting experts in related field to assess nurse residents' knowledge about nursing residency program.

\section{It consisted of two parts:}

Part 1: Demographic data of the Nurse resident:. It included: age, gender and University.

Part 2: Nurse residents' Knowledge about nursing residency program: This part consists of questions about nursing residency program e.g.: definition of nursing residency program \& nurse residents', reasons for nursing residency program, ....etc.

Scoring system: Nurse residents' responses were measured on a 2-point $\quad 1=$ Complete" and $0=$ Incomplete". The knowledge level was considered:

low if the percent score was $<60 \%$

sufficient from $60 \%-<80 \%$

high if the percent score was $\geq 80 \%$ or more (Allison, 2015). 
Tool 2: Nurse residents' perception questionnaire: It was developed by the researcher after reviewing relevant literature (Casey \& Fink, 2014 \&

Allison, 2015) and consulting experts in related field to assess nurse residents' perception of nursing residency program in Egypt and to assess the nurse residents' roles as they perceived in hospitals. It consists of (46 items). These items were grouped under two parts:

\section{Part 1: Nurse residents' perception of nursing residency program.}

\section{Part 2: Nurse residents' perception of nurse residents' roles.}

Scoring system: Nurse residents' responses were measured on a 5-point Likert scale ranging from " $1=$ Nurse residents have strongly disagree and $5=$ Nurse residents have strongly agree. The perception was considered positive if the percent score was $\geq 60 \%$ or more and negative if the percent score was $<60 \%$.

\section{Procedure:}

The actual fieldwork started at the beginning of July 2016, and was completed by the end of December 2016. The researcher met the Dean of each Faculty of Nursing in Helwan University, Ain Shams University, Assiut University, and the nursing director of Badr University Hospital to explain the aim of the study to gain their approval on data collection. The researcher collected data by himself through meeting the subjects and explaining the purpose of the study to them in the study settings. The questionnaire sheets were distributed and completed by nurse residents. The researcher was present all the time during fulfilling the forms to answer any questions. The time needed by nurse residents' to complete the first tool was ranged between (10-15) minutes and the second tool was ranged between (20-30) minutes. The researcher checked the completeness of each filled sheet after the nurse residents' completed it to ensure the absence of any missing data.

\section{Ethical consideration:}

Prior study conduction, approval was obtained from the scientific research ethical committee in Faculty of Nursing/ Helwan University. In addition, an approval was obtained from the Dean of each Faculty of Nursing in Helwan University, Ain Shams University, Assiut University, and also the nursing director of Badr University Hospital for data collection. The study subjects were informed about research purposes, they assured that anonymity and confidentiality would be guaranteed and they informed that they allowed 
choosing to participate or not in the study and that they have the right to withdraw from the study at any time.

\section{Statistical design:}

Numerical data were presented as mean, standard deviation, median and range values. Qualitative data were presented as frequencies (n) and percentages (\%).Data were described and analyzed using the SPSS statistical package-version 22 for windows.

Weighting of the answers of the 7 knowledge questions was performed: (1) for the complete answer and (0) for the incomplete one giving a scale ranged from 0 (if all the responses were incomplete) to 7 (if all the answers were complete). Summation of the individual's answers gives the total knowledge score. Weighting of the answers of the 46 perception questions was performed: (1) for disagree (Summation of strongly disagree and disagree) till (3) for the agree (Summation of strongly agree and agree) (except for the negative statement on table(4) items of "Is a time consuming program for graduates" the reverse was used) giving a scale ranged from (3) if all the responses were disagree to (1) if all the answers were agree. Summation of the individual's answers gives the total perception score.

Pearson's correlation coefficient was used to determine significant correlations between different quantitative variables. Student's t-test was used to compare between knowledge, perception mean scores in males and females. One-way ANOVA test was used to compare between knowledge, perception mean scores among residents from different universities. The significance level was set at $\mathrm{P} \leq 0.05$.Cronbach's alpha coefficient was used to determine the reliability of the tool.

\section{RESULTS:}

\section{Personal characteristics, Table (1):}

The study revealed that $(77.6 \%)$ of the study subjects were females. While, (22.4) were males. Additionally, (55.2\%) of them were from faculty of nursing Assiut University. Also, (32.8\%) of them were from faculty of nursing Helwan University. And only, (11.9\%) of them were from faculty of nursing Ain-Shams University. The mean score of the study subjects' age were $(25.7 \pm \mathbf{1 . 2})$ years ranging from 24 to 31 years.

Nurse Residents' knowledge about nursing residency program, Table (2): 
The study subjects had that the highest percentages of complete answers (74.6\%) were found for the item "advantages of nursing residency program" (74.6\%) and the item "disadvantages of nursing residency program" (70.1\%). While, the lowest percentage of complete answers $(43.3 \%)$ were found with item "reasons for nursing residency program". The mean knowledge score was $4.3 \pm 1.7$.

Nurse residents' perception of nursing residency program, Table (3):

The Study subjects had the highest percentage of agree $(88.1 \%)$ was found with item (One of the requirements for being an academic instructor in your faculty is to pass two years of nursing residency program) followed by item (It provides new graduate nurses opportunities to build clinical skills in real settings \& It provides good opportunity for graduate studies and scientific research in nursing for nurse resident) with $(83.6 \%)$ of agree. While, they had the lowest percentage of agree $(23.8 \%)$ was found with item (It increase salary levels for all graduates). Additionally, they had the highest percentage of undecided (26.9\%) was found with item (It provides new graduates' ability to apply all nursing practices.). While, they had the lowest percentage of undecided $(4.5 \%)$ was found with item (One of the requirements for being an academic instructor in your faculty is to pass two years of nursing residency program.). Conversely, they had the highest percentage of disagree (56.8\%) was found with item (It increase salary levels for all graduates). While, they had the lowest percentage of disagree (3\%) was found with items (It provides new graduate nurses opportunities to build clinical skills in real settings \& It provides good opportunity for graduate studies and scientific research in nursing for nurse resident). The mean perception score of nursing residency program was $36.43 \pm 5.24$.

Nurse residents' perception of their roles at different studied universities, Table (4):

The study results showed that there was no statistically significant differences between the three studied universities as regard the mean scores of the study subjects' perception of nurse residents' roles with P-Value $>0.05$.

Correlation between personal characteristics, knowledge scores and perception scores, Table (6):

There was no statistically significant correlation between personal characteristics, total knowledge scores and total perception scores $(\mathrm{P}>0.05)$. 
Comparison between study subjects at different universities about knowledge and perception scores, Table (7):

As regards mean knowledge score, the study subjects from Ain-Shams University had the highest mean score (5.1). while, the study subjects from Helwan University had the lowest mean score (3.6). The difference between the subjects' mean knowledge scores was statistically significant since $(\mathbf{P}=\mathbf{0 . 0 3 8})$.

For the mean perception score; the same result was observed as the study subjects from Ain Shams university had the highest mean score (193.8). While, the study subjects from Helwan University had the lowest mean score (177.0). However, the difference between the subjects' mean perception scores was statistically in significant since $(\mathbf{P}=$ 0.082).

Table (1): Percentage distribution of personal characteristics of the study subjects $(\mathrm{No}=67)$.

\begin{tabular}{|l|l|l|}
\hline Personal characteristics & No & $\%$ \\
\hline • Gender & & \\
$\bullet$ Male & 15 & 22.4 \\
\hline Female & 52 & 77.6 \\
\hline • Unelwan & & \\
$\bullet$ Ain-Shams & 22 & 32.8 \\
$\bullet$ Assiut & 8 & 11.9 \\
\hline Age (years) & 37 & 55.2 \\
*Mean \pm SD & $25.7 \pm 1.2$ & \\
*Median (Range) & $26.0(24.0-31.0)$ \\
\hline
\end{tabular}


Table (2): Percentage distribution of nurse residents' knowledge about nursing residency program $(\mathrm{No}=67)$.

\begin{tabular}{|l|l|l|l|l|}
\hline \multirow{2}{*}{ knowledge about nursing residency program } & \multicolumn{2}{l|}{ Complete } & \multicolumn{2}{l|}{ In complete } \\
\cline { 2 - 6 } & No & $\%$ & No & \% \\
\hline Definition of nursing residency program & 45 & 67.2 & 22 & 32.8 \\
\hline Definition of nurse residents & 33 & 49.3 & 34 & 50.7 \\
\hline Reasons for nursing residency program & 29 & 43.3 & 38 & 56.7 \\
\hline $\begin{array}{l}\text { - Factors contributing to nurse residents' enrollment to } \\
\text { the nursing residency program in faculties of nursing. }\end{array}$ & 43 & 64.2 & 24 & 35.8 \\
\hline Requirements of nursing residency program & 41 & 61.2 & 26 & 38.8 \\
\hline Advantages of nursing residency program & 50 & 74.6 & 17 & 25.4 \\
\hline Disadvantages of nursing residency program & 47 & 70.1 & 20 & 29.9 \\
\hline $\begin{array}{l}\text { Total knowledge score (Out of 7 marks) } \\
\text { Mean } \pm \text { SD }\end{array}$ & $4.3 \pm 1.7$ & & \\
\hline
\end{tabular}

Table (3): Percentage distribution of nurse residents' perception of nursing residency program $(\mathrm{No}=67)$.

\begin{tabular}{|c|c|c|c|c|c|c|}
\hline \multirow[t]{2}{*}{ Nurse residency program } & \multicolumn{2}{|c|}{ Agree } & \multicolumn{2}{|c|}{ Undecided } & \multicolumn{2}{|c|}{ Disagree } \\
\hline & No & $\%$ & No & $\%$ & No & $\%$ \\
\hline $\begin{array}{l}\text { 1- It is an effective program designed to help new graduates } \\
\text { transition into the professional nurse role. }\end{array}$ & 47 & $\begin{array}{l}70 . \\
1\end{array}$ & 8 & $\begin{array}{l}11 . \\
9\end{array}$ & 12 & $\begin{array}{l}17 . \\
9\end{array}$ \\
\hline $\begin{array}{l}\text { 2- It provides new graduate nurses opportunities to build clinical } \\
\text { skills in real settings. }\end{array}$ & 56 & $\begin{array}{l}83 . \\
6\end{array}$ & 9 & $\begin{array}{l}13 . \\
4\end{array}$ & 2 & 3.0 \\
\hline 3- It is an effective way to solve the nursing shortage problem. & 42 & $\begin{array}{l}62 . \\
7\end{array}$ & 13 & $\begin{array}{l}19 . \\
4\end{array}$ & 12 & $\begin{array}{l}17 . \\
9\end{array}$ \\
\hline 4- It is a time consuming program for graduates. & 26 & $\begin{array}{l}38 . \\
3\end{array}$ & 8 & $\begin{array}{l}11 . \\
9\end{array}$ & 33 & $\begin{array}{l}49 . \\
3\end{array}$ \\
\hline 5- It increase salary levels for all graduates & 16 & $\begin{array}{l}23 . \\
8\end{array}$ & 13 & $\begin{array}{l}19 . \\
4\end{array}$ & 38 & $\begin{array}{l}56 . \\
8\end{array}$ \\
\hline 6- It is a requirement for future employment & 44 & $\begin{array}{l}65 . \\
6\end{array}$ & 15 & $\begin{array}{l}22 . \\
4\end{array}$ & 8 & $\begin{array}{l}12 . \\
0\end{array}$ \\
\hline 7- It increase specialization in nursing areas. & 50 & 74. & 12 & 17. & 5 & 7.5 \\
\hline
\end{tabular}




\begin{tabular}{|l|l|l|l|l|l|l|}
\hline & & 6 & & 9 & & \\
\hline $\begin{array}{l}\text { 8- It provides good opportunity for graduate studies and } \\
\text { scientific research in nursing for nurse resident. }\end{array}$ & 56 & $\begin{array}{l}83 . \\
6\end{array}$ & 9 & $\begin{array}{l}13 . \\
4\end{array}$ & 2 & 3.0 \\
\hline $\begin{array}{l}\text { 9- One of the requirements for being an academic instructor in } \\
\text { your faculty is to pass two years of nursing residency program. }\end{array}$ & 59 & $\begin{array}{l}88 . \\
1\end{array}$ & 3 & 4.5 & 5 & 7.5 \\
\hline $\begin{array}{l}\text { 10- It provides new graduates' ability to apply all nursing } \\
\text { practices. }\end{array}$ & 43 & 64. & 18 & 26. & 6 & 9.0 \\
\hline \multicolumn{1}{|l|}{ Mean $\mathbf{S D}$} & $36.43 \pm 5.24$ & & \\
\hline
\end{tabular}

Table (4): Mean scores of the nurse residents' perception of their roles at different studied universities $(\mathrm{No}=67)$.

\begin{tabular}{|c|c|c|c|c|c|c|c|c|}
\hline \multirow[t]{2}{*}{ Nurse residents' roles } & \multicolumn{2}{|c|}{$\begin{array}{l}\text { Helwan } \\
\text { No } 22\end{array}$} & \multicolumn{2}{|c|}{$\begin{array}{l}\text { Ain-Shams } \\
\text { No } 8\end{array}$} & \multicolumn{2}{|c|}{$\begin{array}{l}\text { Assiut } \\
\text { No } 37\end{array}$} & \multirow[t]{2}{*}{$f$-value } & \multirow[t]{2}{*}{$P$-value } \\
\hline & Mean & SD & Mean & SD & Mean & SD & & \\
\hline Technical skills & 38.36 & 5.36 & 42.25 & 5.23 & 40.32 & 4.70 & 2.070 & 0.135 \\
\hline Safety & 12.82 & 1.65 & 13.00 & 1.85 & 12.97 & 1.42 & 0.079 & 0.924 \\
\hline Professionalism & 34.82 & 5.52 & 37.38 & 4.21 & 36.62 & 4.65 & 1.230 & 0.299 \\
\hline Communication skills & 17.91 & 2.27 & 18.25 & 1.98 & 17.84 & 2.02 & 0.127 & 0.881 \\
\hline Management Role & 20.05 & 3.98 & 21.00 & 2.73 & 19.35 & 3.97 & 0.680 & 0.510 \\
\hline Informatics & 7.00 & 2.64 & 9.13 & 0.99 & 7.81 & 2.13 & 2.778 & 0.070 \\
\hline Scientific research & 10.77 & 3.60 & 13.13 & 1.36 & 12.03 & 2.69 & 2.285 & 0.110 \\
\hline
\end{tabular}

$*$ : Significant at $\mathrm{P} \leq 0.05 * *$ :

Table (5): Pearson's correlation coefficient between total knowledge scores and total perception scores.

\begin{tabular}{|l|l|}
\hline Correlation coefficient & $\boldsymbol{P}$-value* \\
\hline 0.137 & 0.268 \\
\hline
\end{tabular}

*: Significant at $\mathrm{P} \leq 0.05 * *$ :

Table (6): Pearson's correlation between age and knowledge and perception scores.

\begin{tabular}{|l|l|l|}
\hline Variable & $\begin{array}{l}\text { Correlation } \\
\text { coefficient }\end{array}$ & $\boldsymbol{P}$-value \\
\hline Knowledge score & -0.012 & 0.925 \\
\hline Perception score & -0.08 & 0.522 \\
\hline
\end{tabular}

$*$ : Significant at $\mathrm{P} \leq 0.05 * *$ : 
Table (7): Comparison between mean scores in males and females as regard the knowledge and perception scores .

\begin{tabular}{|c|c|c|c|c|c|c|}
\hline \multirow{2}{*}{ Items } & \multicolumn{2}{|l|}{ Males } & \multicolumn{2}{|c|}{ Females } & \multirow{2}{*}{$t$-value } & \multirow{2}{*}{$P$-value } \\
\hline & Mean & SD & Mean & SD & & \\
\hline Knowledge score & 4.6 & 1.5 & 4.2 & 1.8 & 0.775 & 0.441 \\
\hline Perception score & 182.9 & 19.51 & 182.4 & 18.48 & 0.097 & 0.923 \\
\hline
\end{tabular}

*: Significant at $\mathrm{P} \leq 0.05 * *$ :

Table (8): Comparison between mean scores of the study subjects at different studied universities as regard knowledge and perception scores.

\begin{tabular}{|c|c|c|c|c|c|c|c|c|}
\hline \multirow{2}{*}{ Items } & \multicolumn{2}{|c|}{ Helwan } & \multicolumn{2}{|c|}{ Ain-Shams } & \multicolumn{2}{|c|}{ Assiut } & \multirow{2}{*}{$f$-value } & \multirow{2}{*}{$P$-value } \\
\hline & Mean & SD & Mean & SD & Mean & SD & & \\
\hline Knowledge score & 3.6 & 1.7 & 5.1 & 1.2 & 4.5 & 1.7 & 3.442 & $0.038^{*}$ \\
\hline Perception score & 177.0 & 18.6 & 193.8 & 15.7 & 183.4 & 18.3 & 2.598 & 0.082 \\
\hline
\end{tabular}

$*$ : Significant at $\mathrm{P} \leq 0.05 * *$ :

\section{DISCUSSION:}

The aim of this study was to explore the nurse residents' perception of nursing residency program in Egypt through: assess the nurse residents' knowledge about nursing residency program and determine the nurse residents' perception of nursing residency program in Egypt.

The study results revealed that the majority of the nurse residents were females and the majority of them were aged 26 years. Also, the study results revealed that there was no statistically significant difference between age, gender, knowledge scores and perception scores

These study findings showed that more than half of the nurse residents had a sufficient knowledge about nursing residency program. These results were consistent with (Goode et al, 2013 and Allison, 2015) who reported that nurse resident had excellent level of knowledge about the description of the nursing residency program 
Nurse Residents are the new graduates participating in the nurse residency program after the completion of the internship year (Supreme Council of Universities, 2010). The present study revealed that near to half of the nurse residents had low level of knowledge about definition of nurse residents.

It was attending in the study results that the nurse residents have a positive perception about nursing residency program. This results were supported by (Williams et al, 2007) who found the same results that nurse residents had positive perception about residency program .

The current study indicated that the majority of the nurse residents had a positive perception about their roles. These results were consistent with the findings of (Dracup \& Morris, 2007 and Lens, 2011) which found nurse residents had a positive perception about their roles as technical, management,.etc.

It was attending in the study results that there was a weak positive correlation between knowledge scores and perception scores. These findings were consistent with (Park \& Jones, 2010 and Amritpal, 2013) who found that there was a weak positive correlation between nurse residents" knowledge scores and their perception scores about residency program.

The present study indicated that there was no statistically significant difference at three universities regarding nurse resident's knowledge and perception scores about nursing residency program. These results were against the researcher point of view because the researcher expected that nurse residents from Assuit University to be the highest University in all scores as nursing residency program started first in Assuit university from a long time but in Helwan University and Ain-Shams University began in 2014-2015 so residents from Assuit University should be aware about the full data of the nursing residency program.

\section{CONCLUSION:}

Based on the study findings, it can be concluded that nurse residents had sufficient knowledge about nursing residency program. Moreover, they had positive perception about nursing residency program and their roles. Finally, there was a weak positive correlation between knowledge and perception scores. 


\section{RECOMMENDATIONS:}

This study aimed to explore the nurse residents' perception of nursing residency program in Egypt. Descriptive research design was used in this study. The study subjects included (67) nurse residents' from Helwan University, Ain Shams University and Assiut University. Two tools were used for data collection included: Nurse residents' Knowledge questionnaire and Nurse residents' perception questionnaire: The study results revealed that nurse residents had sufficient knowledge and positive perception about nursing residency program. The study concluded that there was a weak positive correlation between knowledge and perception scores: Based on the study findings, it is needed to disseminate the nursing residency regulation to all faculties of nursing in Egypt to follow it.

\section{REFERENCES:}

Allison, $\quad K . \quad$ (2015). New graduate nurse residency program development doi: 10.1172/JCI84236

American Association of Colleges of Nursing. (2014).CCNE accreditation. Retrieved July 5, 2014, from http://www.aacn.nche.edu/ccne-accreditation .org/s05152013/joboffer-acceptance-rate.aspx

Amritpal, K., \& Kambo, j. (2013) Nurse residency: an answer to improve new graduate nurse competency $88-113$.

Association of Registered Nurses of Newfoundland and Labrador. (2014). Orientation Programs for Registered Nurses: Best Practice Guidelines. ARNNL .Council Policy Ends, St. John’s, NL:

Benner, P., Sutphen, M., Leonard, V., \& Day, L. (2010). Educating nurses A call for radical transformation, San Francisco CA;Jossey-Base. 401-06. Doi:10.1097/BBA.)b013c31822edd79

Casey, K., \& Fink, R. (2014). Casey-Fink Graduate Nurse Experience Survey Reliability and Validity. Retrieved from University of Colorado Health:http://www.uch.edu/for-healthcare-professional/professional-resouces/caseyfinksurvey- instruments/grad-nurse-experience/ 
Commission on Collegiate Nursing Education. (2008). Standards for accreditation of post-baccalaureate nurse residency programs. Retrieved from www.aacn.nche. edu/ccne-accreditation/resstandards08.pdf. 29, 205-211.

Dracup, K., \& Morris, $\boldsymbol{P}$. (2007). Nurse residency programs: Preparing for the next shift. American Journal of Critical Care, 16(4), 328-330.

Goode, C., Lynn, R., McElroy, D., Bednash, D., \& Murray, B. (2013). Lessons learned from 10 years of research on a post-baccalaureate nurse residency program. Journal of Nursing Administration, 43(2), 73-9.

Harris, C. (2014). Bridging the gap between acute care nurse practitioner education and practice: the need for postgraduate residency programs. J Nurse Pract; 10(5):3316.

Institute of Medicine. (2011). The future of nursing: Leading change, advancing health. National Academies Press, Washington, D.C. DOI 10.17226/12956

Lens, M. (2011) RN Transition to Practice Program in the Primary Care and School Settings: Development, Implementation, and Evaluation.

National Academy of Sciences. (2012). [IOM Report Recommendations] The future of nursing leading change, advancing health. Last updated 11/19/2010. Retrieved on January 28, 2012 from http://www.iom.edu/Reports/2010/The-Future-of-NursingLeading-Change-Advancing Health/Recommendations.aspx?page=2

National Council of State Boards of Nursing. (2009). Transition to practice: Promoting public safety. Chicago, IL: doi: 10.1097/NCB.0b012e31719aa130

Park, M., \& Jones, C. (2010). A retention strategy for newly graduated nurses: An integrative review of orientation programs. Journal for Nurses in Staff Development, 26(4), 142-151. doi: 10.1097/NND.0b013e31819aa130.

Supreme Council of Universities, (2010). Nursing Residency Program, regulation of nursing residency program: http:/nurse residents' role and duties in Egypt. 
Staiger, D., Auerbach, D., \& Buerhaus, P. (2012). Registerd Nurse Labor Supply and the Recession- Are We In a Bubble? The New England Journal of Medicine (366), $1463-1465$

Theisen, J., \& Sandau, K. (2013). Competency of New Graduate Nurses:

Review of Their Weaknesses and Strategies for Success. The Journal of Continuing Education in Nursing, 44(9), 406-414.

Ulrich, B., Krozek, C., Early, S., Ashlock, C., , Africa, L., \& Carman, M. (2010). Improving retention, confidence, and competence of new graduate nurses: Results from a 10- year longitudinal study. Nursing Economic\$, 28 (6), 363-375.

Varner, K., \& Leeds, R. (2012). Transition within a graduate nurse residency program- Journal Of Continuing Education In Nursing; 43(11), 491-499.

Versant. (2014). Transitioning new graduates to practice. Retrieved from https://versant.org/professional-services/versant-new-graduate-rn-residency.html

Williams, C., Goode, C., Krsek, C., Bednash, G, \& Lynn, M. (2007). Post baccalaureate nurse residency 1- year outcomes. The Journal of Nursing Administration 37,35(7) -365 . 
إدر اك نواب التمريض لبرنامج النيابة في التمريض في مصر

حسام علي إسماعيل الصياد1 1.د/ ايمان سالمان طايع، ا.د/ سماح محمد عبد الله 3

أستاذ ادرة التمريض جامعة طوان، أستاذ ادرة التصريض جامعة أسيوط

\section{الخلاصة}

يعد النقص في التمريض من القضايا المثيرة للقلق علي الصعيد العالمي وفي مصر .يو اجه الخريجون الجدد العديد من الصعوبات أثناء الانتقال من طالب إلي دورة كمهني وذللك بسبب الفجوة بين الدر اسة ومنطلبات الحياة العملية. برنامج النيابة في التمريض هو برنامج مصصم للخريجين الجدد لتسهيل عملية الانتقال للحياة العملية وبناء كو ادر مهنيه تساهم في تطوير التمريض.تهدف الدراسة الحالية إلي اكتثاف مدى إدراك نواب التمريض

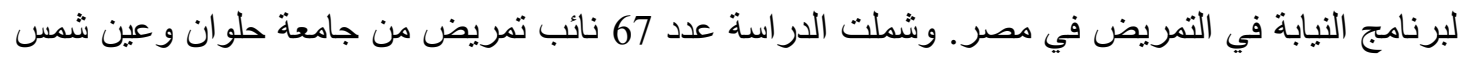
و أسيوط. وقد تم استخدام أداتين لجمع البيانات وهم استبيان لمعرفه النواب و أخر لقياس إدر اكهم لبرنامج النيابة. وقد أسفرت نتائج البحث عن وجود مستوي كافي من المعرفة و إدر الك ايجابي عن البرنامج. وخلصت الرسالة إلي وجود علاقة ايجابية بين مستوي المعرفة ومدي الإدراك.وبناءا علي نتائج الدراسة هنالك الحاجة إلي تعميم اللائحة الخاصة بالنيابة في التمريض في كل كليات التمريض. 